\title{
The Effectiveness of Phonics Approach in Teaching Reading
}

\author{
1Atika Salman Paris \\ ${ }^{1}$ Mataram University, Mataram, Indonesia \\ atikasalmanparis@gmail.com
}

\begin{tabular}{|c|c|}
\hline Article Info & Abstract \\
\hline $\begin{array}{l}\text { Article History } \\
\text { Received: July 12, } 2018 \\
\text { Accepted: September 30, } \\
2018 \\
\text { Keywords } \\
\text { Phonics Approach; } \\
\text { Teaching; Reading; Pre- } \\
\text { Experimental. }\end{array}$ & $\begin{array}{l}\text { This research aimed to determine the effectiveness of phonics approach in } \\
\text { teaching reading for the seventh graders of SMP Negeri } 1 \text { Aikmel, East } \\
\text { Lombok, and to what extent it is effective. This research was designed as } \\
\text { pre-experimental with read aloud test as the instrument to collect data. The } \\
\text { sample of this research consisted of } 36 \text { students of SMP Negeri } 1 \text { Aikmel. The } \\
\text { sample was taken through purposive sampling. In collecting the data, a pre- } \\
\text { test and a post-test were given to the students. SPSS } 17 \text { for Windows and } \\
\text { paired-sample t-test were applied to analyze the collected data. After, } \\
\text { calculating the data, it could be known that there was a significant } \\
\text { difference in the mean scores between pre-test and post-test, t(df=35) = } \\
\text { 23.314 at } p=0.001, \text { meaning that the null hypothesis was rejected and the } \\
\text { alternative hypothesis was accepted. In a nutshell, phonics approach was } \\
\text { significantly effective in teaching reading for the seventh graders of SMP } \\
\text { Negeri } 1 \text { Aikmel. }\end{array}$ \\
\hline $\begin{array}{l}\text { Support by: } \\
\text { doI Crossref }\end{array}$ & This is an open access article under the CC-BY-SA license \\
\hline
\end{tabular}

\section{INTRODUCTION}

Reading is typically an individual activity, although on occasion a person will read out loudly the benefit of other listeners. Reading is the ability that needs fluency and accuracy in reading text books. In word recognition, this focuses on a reader's ability to identify the words correctly on first attempt. "When a word is identified correctly, the meaning from the reader's oral vocabulary makes sense with other in the sentence".

Reading capability is necessary, especially for students, because they need to read a lot of books in English. Reading to young children is a recommended way to instill language and expression, and to promote comprehension of text. According to Danielle (2007:3), reading is an extraordinary achievement when one considers the number of levels and components that must be mastered. Therefore, the students should read the material in order to get fluency in reading.

To acquire reading capability, students need to know several factors relate to efficient strategies in reading, they must understand the meaning, understand the relationships in the texts, understand the important points, and reading efficiently. "There is much that we can say about both the nature of reading comprehension as a process and about effective reading comprehension instruction" (Duke and Pearson, 2002: 205).

In fact, the students have many problems in reading comprehension. In SMP Negeri 1 Aikmel, for example, there was much error of sound when students read text and more students read English vocabularies like the written language. Besides, the students less interest to read English texts book as the first problem in reading comprehension. 
Referring to the problems in teaching reading, teachers should change instructional teaching activities utilizing appropriate teaching approach. Phonics approach is some methods to enable beginning readers to decode new written words by sounding out, or in Phonics terms, blending the sound spelling patterns. Adams (1994) argues that the Phonics and the whole language advocates are both right, and that Phonics is an effective way to teach students the alphabetic code, building their skills in decoding unknown words.

Phonies approach is probably the best known and widely uses approach to teach reading and writing in English language. Teaching students to understand the alphabetic principle is important for successful reading. It relies on students teach the alphabet first and students learn the names of the letters and sounds. If the students already know the letters, it makes sense to use this for new knowledge about the sound.

Students need to teach clearly that letters have a name and make a sound. Several Phonics schemes begin by teaching students the sounds that letters make, and teach the letters name. Phonics approach can help the students to learn the letters and sounds. It was begin by considering key factors that influence how students learn to read and then attend more specifically to words recognize and the role of Phonics. Where, in Phonics approach the students learn about letters and sounds to reconstruct the words by blending the letters. Because, teaching students to understand the alphabetic principle is important for successful reading.

Therefore, it is important for students to learn the relationship between letters and sounds. "Phonics is the understanding that there is a predictable relationship between phonemes (the sounds of spoken language) and graphemes (the letters and spellings that presents those sounds in written language)" (Sarwono, 2013). It means that, based on the method the students study reading comprehension about the relationship between letters and sounds. This method can help the students how to read words of English well.

\section{Reading}

Reading is considered by many teachers, textbook writers and language test constructors to be made up of different skills and components. It is often claimed that sets of reading components provide useful frameworks on base course design, teaching, and test development. Besides, reading is a complex cognitive process of decoding symbols in order to construct or derive meaning (reading comprehension). It means that language acquisition of communicate, sharing information and ideas. According to Harmer (2007:99) reading is useful for language acquisition, which provided information about what they read and what they get in reading activities.

Furthermore, reading can be defined as the ability of an individual to recognize a visual form; associate the form with a sound and or meaning acquired in the cover and on the part of experience, understands, and interprets its meaning. In the process of reading, readers get information about the message or information that has been stated. Day and Bamford (1998), say that reading contains the construction of meaning from printed or written material followed by the readers understanding about what they have read.

\section{Phonics}

Phonics is a tool needed by all readers and writers of alphabetically written language such as English. Teaching and learning by using phonics actually need learners to identify words quickly and accurately. Brand (2004) says that phonics is one of the instructions that can help students to understand the sound of the letter in reading and spelling. This approach focuses on how the readers' understanding about the letters and how to pronounce them correctly in reading activities. 
Furthermore, Bald (2007), states that Phonics is the systematic teaching of the sounds conveyed by letters and groups of letters, and includes teaching children to combine and blend these to read or write words. This approach encourages learners to decode written letters by sound based on the grapheme. In addition, phonics approach gives some advantages to the learners, especially for children learning to read in the early age. It will allow students to learn the regular pattern of words including the rules of letters pronunciation, it is allowing for easier reading.

\section{METHOD}

The method used in this study was a pre-experimental research. Daniel (2004) states that an experimental design is sometimes known as the scientific method due to their popularity in scientific research where they originated. Then he said that the basis of the experimental method is the experiment, which can be defined as: a test under controlled conditions that is made to demonstrate the know truth or examine the validity of a hypothesis.

Furthermore, this study aimed at knowing the effectiveness the effectiveness of Phonics approach in teaching reading. Therefore, this study established the regular instruction to one group that is experimental group. This group was treated by using Phonics approach and it was given the pre-test and post-test. Objective test was given to the students in form of descriptive text. This study then required students to read the text in order to know the pronunciation, fluency, accuracy, and phoneme awareness.

In collecting the data, this study took the data from pre-test and post-test. Pre-test was given to the subject before the present researcher doing teaching and learning process by using the phonics approach. The pre-test was given for knowing the students' prior knowledge in reading. Meanwhile, post-test was given after applying the phonics approach which was aimed at knowing students' achievement. Before conducting post-test, however, the treatment was given to the experimental group by applying phonics approach.

The population in this study was the seventh graders of SMP Negeri I Aikmel in the school year 2014-2015 consisted of 244 students that were divided into seven classes. However, the experimental group was VIIA class consisted of 36 students. It was taken through cluster random sampling technique.

The data of this study was collected and analyzed by using descriptive statistic. Descriptive statistic is used to know the mean and standard deviation of students score in reading test. The study then calculated the mean and standard deviation of the experimental group by using SPSS 17 for Windows.

The collected data should be normal and homogenous. There are two required statistic, namely Normal Distribution and Homogeneity that was tasted by using SPSS 17 for Windows. The study used One-Sample Kolmogorov Z Test to calculating Normal Distribution, and the present researcher used One-Way ANOVA to calculate homogeneity of the variance of the variable. This study performed a paired simpleample t-test by using SPSS 17 for Windows to measure the collected data. This was aimed at knowing whether the alternative hypothesis was accepted or not.

\section{RESULT}

Descriptive statistics was concerned to know the mean score and the standard deviation of data which were collected from pre-test and post-test before calculating hypothesis testing. Based on data gained, therefore, the lowest and the highest students' score in pre-test were 6 and 12, while in post-test obtained the lowest and the highest score were 13 and 18. The Standard Deviation of pre-test was 1.079 and post-test was 
1.457. The mean score of pre-test was 8.860 , while the mean score of post-test was 15.860. That result showed that, mean score of posttest was higher than mean score of pre-test. In other word, the mean score after approach was higher than before treatment was conducted. It proved that, phonics approach was significantly effective in teaching reading.

Before testing hypothesis, however, the data must be normal and homogenous. The calculation of normality testing was used to know whether the distribution of pre-test and post-test were normal or not. Moreover, the data was said to be normal if the values of the significance level of pre-test and post-test were more than the values of the significance $(\mathrm{p})=0.05$. After calculating normality test by using one-sample K-S test (SPSs 17 for windows), the values of Kolmogorov-Smirnov in pre-test and post-test were more than the values of the significance $(p)=0.05$. The value of KolmogorovSmirnov in pre-test was 0.861 and in post-test was 1.030 , while values of the asymp. Sig. (2-tailed) of pre-test was 0.449 and post-test was 0.239 . Those all values were higher than the two-tailed at 0.05 . It proved that the data was normal.

Next test was homogeneity testing, this test was done to know whether the data homogenous or not. Moreover, the data was said to be homogenous, if the values of the significance level of pre-test and post-test are greater than $p=0.05$. Based on the calculation of One-Way ANOVA (SPSS 17 for windows), the value of Levene's Statistic was 0.716 at $p=0.400$. The value of $p=0.400$ was greater than 0.05 , it implied that the data was homogenous.

After the data was proven to be normal and homogenous, this study calculated hypothesis testing to know whether the alternative hypothesis was accepted or rejected. The hypothesis of this research is Phonics approach was effective in teaching reading for the seventh graders of SMN 01 Aikmel in the school year 2014-2015. This study used paired sample t-test in analyzing the data to get the answer of the hypothesis. The alternative hypothesis $(\mathrm{Ha}$ ) was accepted if the value of significant level was lower 0.05 and the value of t-test was higher than 0.05 .

After calculating paired sample t-test, the result of the value was $t(d f=35)=22341$ at level significant ( 2 tailed) $p=0.000$. Those results showed that, the value of level sig ( 2 tailed) $p=0.000$ was lower than 0.05 while the value of t-test was higher than 0.05 so the alternative hypothesis (Ha) was accepted and the null hypothesis (Ho) was rejected. As the conclusion, Phonics approach significantly effective in teaching reading for the seventh graders of SMP Negeri I Aikmel in the school year 2014-2015.

Reading is an active process of comprehending the meaning of texts by understanding meaning and understanding important points to find information of the texts, including some elements: phonemics awareness, phonics, vocabulary, fluency as well as comprehension. Therefore, teachers have to choose an appropriate approach to help students to better understand on the reading activity. Phonics approach is one of the appropriate approaches to teach reading, it can be seen from the finding of this study.

After collecting and calculating the obtained data, the result of the study showed that Phonics approach was effective in teaching reading. It can be seen from the result of calculation descriptive statistics, the result was mean score of post-test was greater than pre-test. It clearly indicated that there was improvement on students' reading comprehension after treatment by using Phonics approach. Additionally, it can be said that the treatment was successful for the seventh graders of SMP Negeri 1 Aikmel in the school year 2014-2015.

Based on the result of testing hypothesis, the study found that there was significant different mean score between pretest and posttest. The result showed that the value of 
significant level was lower than 0.05 . It meant that the alternative hypothesis (Ha) was accepted and the null hypothesis (Ho) was clearly rejected. So, the result of this research can be concluded that Phonics was significantly effective in teaching reading for the seventh graders of SMP Negeri 1 Aikmel in the school year 2014-2015.

The above result of this study in line with expert opinion Morrow (1996), who says that Phonics approach is important for students to learn about the relationship between letters and sound to immediate way to distinguish between cap and cape. Additionally, learning to read with phonics can be extremely effective, especially for children to learn reading at early age. Through phonics approach, students learn the rules of letters' pronunciation. So, it is advisable that teachers use phonics approach in teaching reading writing skill.

\section{CONCLUTION}

Referring to the result of the study, this study synthesized briefly some conclusion. First, phonics approach was effective in teaching reading for the seventh graders of SMP Negeri 1 Aikmel in the school year 2014-2015. It can be seen from the result of the research that post-test score was higher than pre-test with mean score 8.860 for pretest and 15.860 for post-test.

\section{DAFTAR PUSTAKA}

[1] Adam, M. J. (1994). Beginning to read: Thinking and learning about print. London: MIT Press.

[2] Bald, J. (2007). Using Phonics to Teach Reading and Spelling. London: Paul Chapman Publisher.

[3] Brand, M. (2004). Word savvy; integrating vocabulary, spelling and word study. Portland, ME: Stenhouse.

[4] Danielle, S. McNamara. (2007). Reading Comprehension Strategies. Theories, Interventions, and Technologies. University of Memphis

[5] Danielle, S. (2004). Doing quantitative research in education. London: SAGE Publication

[6] Duke, N. K. and Pearson, P. D. (2002). Effective Practices for Developing Reading Comprehension. Third Edition

[7] Morrow, K. (1996). Literature link to phonics. USA. Library of Congress Catalogue in Publication Data.

[8] Sarwono, J. and Purmanto, Y. (2013). English for academic purposes: A successful way to learn scientific English. Yogyakarta. 